\title{
REVIEW
}

\section{Bench-to-bedside review: Sepsis - from the redox point of view}

\author{
Michael Éverton Andrades', Arian Morina², Snežana Spasić ${ }^{3}$ and Ivan Spasojevićz ${ }^{*}$
}

\begin{abstract}
The pathogenesis of sepsis and its progression to multiple organ dysfunction syndrome and septic shock have been the subject of investigations for nearly half a century. Controversies still exist with regard to understanding the molecular pathophysiology of sepsis in relation to the complex roles played by reactive oxygen species, nitric oxide, complements and cytokines. In the present review we categorise the key turning points in sepsis development and outline the most probable sequence of events leading to cellular dysfunction and organ failure under septic conditions. We have applied an integrative approach in order to fuse current state-of-the-art knowledge about redox processes involving hydrogen peroxide, nitric oxide, superoxide, peroxynitrite and hydroxyl radical, which lead to mitochondrial respiratory dysfunction. Finally, from this point of view, the potential of redox therapy targeting sepsis is discussed.
\end{abstract}

\section{Introduction}

Sepsis is a leading cause of death in critically ill patients; the mortality in patients admitted to intensive care units and given both antibiotics and supportive care varies from $20 \%$ up to more than $60 \%[1,2]$. The problem is becoming even more prominent because the frequency of sepsis is increasing due to the prevalence of antibioticresistant pathogens [3]. Historically the widely accepted hypothesis was that sepsis was in fact an uncontrolled inflammatory response. Accordingly, the organism is killing itself while the pathogens are considered as bystanders $[4,5]$. However, this theory was based on animal studies that do not reflect the clinical picture in humans [6]. Studies on animal models usually involve the application of large doses of endotoxin or pathogens, leading to much higher levels of circulating cytokines in

*Correspondence: redoxsci@gmail.com

2Institute for Multidisciplinary Research, University of Belgrade, Kneza Višeslava 1,

11000 Belgrade, Serbia

Full list of author information is available at the end of the article comparison to humans with sepsis and ending in death by 'cytokine storm' [6]. Recent data indicate that the immune system during sepsis actually shows two phases: an initial hyper-inflammatory stage followed by a prolonged hypoinflammatory phase [7]. In addition, numerous studies and trials have shown that the application of antiinflammatory agents is futile, or can even worsen chances of survival $[7,8]$. There are some exceptions, however. For example, Annane and co-workers [9] have shown that the application of selected corticosteroids at moderate doses may decrease the mortality of sepsis. In contrast to prevalently disappointing results for anti-inflammatory therapies, a pro-inflammatory approach seems to be more promising. For example, interferon- $\gamma$, a potent macrophage activator, improved survival of patients with sepsis [10]. IL-12, an immune stimulant, reduced mortality from subsequent sepsis when administered after burn injury [11]. Pertinent to these data, Hotchkiss and Karl [7] have recently proposed a coherent immunological approach in sepsis treatment, consisting of moderate suppression of the immune system during the hyperinflammatory mode in early sepsis and intensive promotion of activity of the immune system during the hypoinflammatory phase.

Immunohistochemical analysis has shown that in the majority of patients with sepsis, only lymphocytes and gastrointestinal epithelial cells die [12]. These two types of cells normally undergo rapid turnover through apoptosis, and sepsis most likely accelerates this process. Cell death in the heart, lungs and kidneys has been observed to be minor, resulting in insignificant damage to these organs [13]. Studies in patients with acute renal failure have illustrated discordance between the level of renal dysfunction and the degree of tubular necrosis [14]. It is very interesting that most sepsis survivors who showed renal failure recover baseline renal function [15], suggesting that changes that may cause death are in fact reversible. It can be concluded that organ failure in sepsis is not provoked by tissue damage, but instead by the dysfunction of a substantial number of cells. A central paradigm in organ dysfunction is the concept of tissue hypoxia; the failure to adequately supply organs with oxygen [16]. However, non-survivors of sepsis exhibit an 
impaired capacity to increase tissue oxygen consumption in response to the augmentation of oxygen delivery [17]. This is reinforced by the fact that well-perfused endotoxaemic model animals still present acidosis [18]. In line with these facts, Fink [19] has postulated that impaired cellular $\mathrm{O}_{2}$ utilisation, rather than inadequate oxygen delivery, may play an important role in sepsis development. As mitochondria represent the main consumers of $\mathrm{O}_{2}$, significant attention has been focused on the role of mitochondrial dysfunction in sepsis [20]. Brealey and coworkers [21] demonstrated that there is an association between mortality in sepsis and mitochondrial dysfunction. In addition, a decrease in the number of mitochondria has been observed in patients with prolonged septic conditions [22], implying that sepsis-related dysfunction of mitochondria may result in mitoptosis. The direct consequence of mitochondrial dysfunction is a significant fall in the level of ATP, as observed in the tissues of model animals and septic patients [21].

An activated immune system and dysfunctional mitochondria represent the two most potent sources of reactive molecular species in organisms [23]. Pertinent to this, it has been documented that sepsis is characterised by excessive production of reactive oxygen species (ROS) and reactive nitrogen species (RNS), both in the circulation (by activated immune system cells and endothelial cells) and in the affected organs (by dysfunctional mitochondria and due to a modified anti-oxidative status) [16,24]. Many authors agree that ROS and RNS (Table 1) play a crucial role in the pathophysiology of sepsis [24-26]. Some of these species interfere with signalling cascades, while others provoke deleterious effects on various biological molecules and structures. It is clear that the increased production of signalling species (for example, nitric oxide ( $\mathrm{NO}$ ) and hydrogen peroxide $\left.\left(\mathrm{H}_{2} \mathrm{O}_{2}\right)\right)$ and strong oxidants (the hydroxyl radical $(\cdot \mathrm{OH})$ and hypochlorous acid $(\mathrm{HOCl})$ ) act in synergy with collapse in energy metabolism to provoke cell dysfunction, which may result in organ failure and death.

When considering possible treatment strategies for sepsis patients, it is crucial to identify the main events in the development of sepsis and the schedule of changes of pathogenic factors. In the present review we focus on redox mechanisms of sepsis without under-estimating any other possible contributors to this pathology. We outline the most probable sequence of redox events leading to cellular dysfunction in sepsis. In addition, the current potential of and prospects for the application of redox therapy in sepsis are discussed.

\section{The chain of redox events Oxidative burst}

A plasma oxidative burst takes place early in sepsis orchestrated by neutrophils, macrophages and endothelial cells
Table 1. The main reactive species implicated in the pathogenesis of sepsis

\begin{tabular}{ll}
\hline Free radicals & Non-radicals \\
\hline $\begin{array}{l}\text { Reactive oxygen species } \\
\text { Superoxide, } \mathrm{O}_{2}^{-}\end{array}$ & Hydrogen peroxide, $\mathrm{H}_{2} \mathrm{O}_{2}$ \\
Hydroxyl radical, $\mathrm{OH}$ & Hypochlorous acid, $\mathrm{HOCl}$ \\
Hydroperoxyl radical, $\mathrm{OOH}$ & \\
Peroxyl radical, $\mathrm{ROO}$ & \\
Reactive nitrogen species & \\
Nitric oxide, $\mathrm{NO}$ & Peroxynitrite, $\mathrm{ONOO}$ \\
Nitrogen dioxide radical, $\cdot \mathrm{NO}_{2}$ & Peroxynitrous acid, $\mathrm{ONOOH}$ \\
\hline
\end{tabular}

[27]. These cells represent the innate immune system, our first line of defence against invading microorganisms. Accordingly, they are equipped with different ROS and RNS [23]. When activated by pathogens they generate superoxide $\left(\cdot \mathrm{O}_{2}{ }^{-}\right), \mathrm{H}_{2} \mathrm{O}_{2}$, $\cdot \mathrm{NO}$ and $\mathrm{HOCl}$, while ${ }^{\cdot} \mathrm{OH}$, peroxynitrite $\left(\mathrm{ONOO}^{-}\right)$, the nitrogen dioxide radical $\left(\cdot \mathrm{NO}_{2}\right)$, the hydroperoxyl radical $(\cdot \mathrm{OOH})$, and the peroxyl radical $(\cdot \mathrm{ROO})$ are produced in secondary reactions (Figure 1$)$. The lack of this intrinsic oxidant system can be deleterious to the host as demonstrated in subjects lacking ${ }^{\circ} \mathrm{O}_{2}$ generation. Mice deficient in NADPH oxidase subunits and humans with chronic granulomatous disease who also lack NADPH oxidase activity are incapable of adequately performing bactericidal functions [28,29]. However, the oxidant system may also significantly modify redox settings in the organism.

Septic plasma shows a number of positive markers of oxidative stress (Table 2). Anti-oxidants scavenge reactive species, which leads to a decrease in the concentration of anti-oxidants. The level of free thiols decreases due to oxidation or nitrosylation. As a result, the total anti-oxidant capacity of plasma is reduced. In addition, uncharged radicals attack membranes, initiating a lipid peroxidation chain reaction (Figure 1, reactions 6 to 8 ). Interestingly, two research groups have reported that the plasma total anti-oxidant capacity in sepsis is initially decreased but increases over time as the condition progresses [30,31]. This indicates that the redox status of plasma during sepsis follows a two-phase pattern characteristic of the immune system.

It is important to note that redox conditions in the plasma of neonates with sepsis seem to be different in comparison to other patient groups. Cherian and colleagues [32] reported that there were no significant changes in the levels of ascorbate, glutathione and oxidative stress biomarkers in the blood of neonates and babies with sepsis when compared to age-matched controls. This may be attributed to the immaturity of the immune system. Neonates have a low neutrophil pool and reduced release of pro-inflammatory cytokines (for 


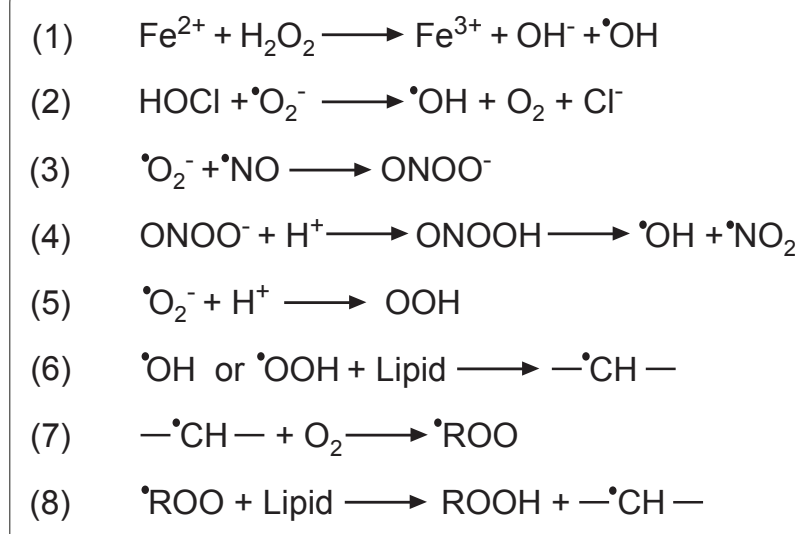

Figure 1. Key redox reactions in living systems [23]. (1) Fenton reaction; (6) to (8) lipid peroxidation $(\mathrm{ROOH})$ chain reactions.

example, TNF- $\alpha$ ), and their neutrophils have an impaired capacity to migrate to sites of infection, which may account for the less prominent oxidative burst in response to infection [33]. Fortunately, neonatal sepsis is very uncommon and shows a relatively low mortality rate of 5 to $10 \%$ (in developed countries) [34]. The presented facts regarding neonatal sepsis strongly imply that pronounced immune system-mediated redox changes may play an important role in sepsis initiation in adults.

Modified redox status of septic plasma affects the intracellular milieu of surrounding tissues due to: (i) the capability of some reactive species, such as $\mathrm{H}_{2} \mathrm{O}_{2},{ }^{\circ} \mathrm{NO}$, and $\mathrm{HOCl}$, to cross cellular membrane [23,35]; (ii) oxidative changes in the membrane (Figure 1, reactions 6 to 8 ) [36]; and (iii) the activation of specific receptors. After entering the cell, $\mathrm{H}_{2} \mathrm{O}_{2}$ and $\mathrm{NO}$ participate in secondary reactions (Figure 1, reactions 1 to 4 ) to produce more reactive species, which provoke intracellular oxidative stress. Due to its high reactivity with biomolecules, $\mathrm{HOCl}$ is predicted to have a very limited diffusion radius in biological systems $[37,38]$. Therefore, only a small fraction of $\mathrm{HOCl}$ manages to enter the cell, where it may provoke protein, DNA, lipid and mitochondria damage [38]. On the other hand, $\mathrm{H}_{2} \mathrm{O}_{2}$ and $\mathrm{NO}$ represent signalling molecules crucial for normal cell function [39]. They activate specific sets of genes via a number of transcription factors at the nuclear level, of which NF- $\mathrm{kB}$ appears to have a central role in sepsis [40]. Other factors, such as nuclear factor E2-related factor 2 (Nrf2), may also be

Table 2. Redox characteristics of plasma in adults with sepsis

\begin{tabular}{|c|c|c|c|c|}
\hline & Patient groups & & Method & Reference \\
\hline \multicolumn{5}{|l|}{ Anti-oxidant } \\
\hline \multirow[t]{2}{*}{ Ascorbate (mg/L) } & Control: $1.71 \pm 0.46$ & Sepsis: $0.55 \pm 0.28$ & $\begin{array}{l}\text { Spectrophotometric } \\
\text { assay }\end{array}$ & {$[116]$} \\
\hline & Control: 4.5 to 12 & Critically injured: $1.1 \pm 0.3$ & HPLC & {$[117]$} \\
\hline Retinol $(\mu \mathrm{g} / \mathrm{L})$ & Control: $735 \pm 183$ & Septic shock: $265 \pm 193$ & HPLC & {$[118]$} \\
\hline$\beta$-Carotene $(\mu \mathrm{g} / \mathrm{L})$ & Control: $619 \pm 259$ & Septic shock: $<101$ & HPLC & {$[118]$} \\
\hline Lycopene ( $\mu \mathrm{g} / \mathrm{L})$ & Control: $522 \pm 184$ & Septic shock: $<154$ & HPLC & {$[118]$} \\
\hline \multicolumn{5}{|l|}{ Oxidative stress biomarkers } \\
\hline Total plasma thiols $(\mathrm{R}-\mathrm{SH})(\mu \mathrm{mol} / \mathrm{L})$ & Control: $364 \pm 22$ & Sepsis: $138 \pm 14$ & Ellman's method & {$[119]$} \\
\hline \multirow{2}{*}{ Lipid peroxidation ( $\mu \mathrm{mol} / \mathrm{L})$} & Control: $0.92 \pm 0.39$ & Sepsis survivors: $0.99 \pm 0.14$ & TBARS assay & {$[120]$} \\
\hline & & Sepsis non-survivors: $3.33 \pm 2.29$ & & \\
\hline Lipid peroxidation (nmol/mg of protein) & Sepsis (day 1): 2.4 & Sepsis (day 7): 2.9 & FOX assay & {$[121]$} \\
\hline $\begin{array}{l}\text { Total anti-oxidant capacity } \\
(\mathrm{nmol} / \mathrm{mg} \text { of protein })^{\mathrm{a}}\end{array}$ & Sepsis (day 1): 1.5 & Sepsis (day 7): 1.1 & ABTS assay & {$[121]$} \\
\hline \multirow[t]{2}{*}{ Total anti-oxidant capacity (\%) } & Control: 57.3 to 60.3 & Survivors: 51.4 to 55.4 & ABTS assay & {$[30]$} \\
\hline & & Non-survivors: 46.1 to 47.6 & & \\
\hline \multirow[t]{2}{*}{ Total anti-oxidant capacity ( $\mu \mathrm{mol} / \mathrm{L})$} & Control: $354 \pm 9$ & Sepsis: $265 \pm 32$ & TRAP assay & {$[31]$} \\
\hline & & Septic shock: $452 \pm 34$ & & \\
\hline
\end{tabular}

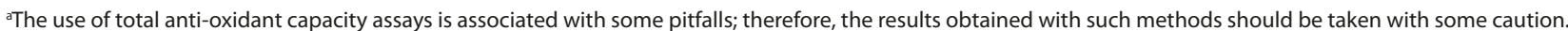
For example, urate interferes with both the ABTS and the TRAP assays, potentially leading to falsely high values [23]. Urate increases in many pathophysiological conditions, for example, in renal failure, which may develop in sepsis. Another problem is that plasma contains a complex mixture of anti-oxidants that react at different rates, so some of them may not be detected by rapid assays [23]. ABTS, 2,2'-azino-bis(3-ethylbenzthiazoline-6-sulphonic acid); FOX, ferrous oxidation-xylenol orange; HPLC, high-performance liquid chromatography; TBARS, thiobarbituric acid reactive substances; TRAP, total radical-trapping antioxidant potential. 
involved. Nrf2 is a transcription factor that regulates antioxidant response element (ARE)-mediated transcription of a plethora of anti-oxidant and protective genes to counteract the harmful effects of ROS or environmental carcinogens. Non-carcinogenic ARE inducers from a variety of chemical classes have been identified to enhance the transcriptional activity of Nrf2 through $\mathrm{S}$-alkylation of reactive cysteines within the cellular redox sensor protein Keap1 (Kelch-like ECH associated protein 1) [41]. Following dissociation from the cytosolic protein Keap1, a scaffolding protein that binds Nrf2 and Cul3 ubiquitin ligase for proteasome degradation, Nrf2 rapidly accumulates in the nucleus and transactivates the ARE in the promoter region of many anti-oxidant genes [42]. Nrf2 seems to represent an important regulator of oxidative stress in sepsis [43]. For example, it has been reported that lipopolysaccharide-induced shock and polymicrobial sepsis induces early and greater mortality in Nrf2-deficent mice, which is related to the lethal innate immune response [44]. In contrast, transgenic mice with a decreased rate of Nrf2 degradation showed lower mortality in polymicrobial sepsis [45]. Consequences of the down-regulation of the Nrf2 host defence mechanism still remain to be fully explored.

\section{Intracellular ${ }^{N} \mathrm{NO}$ generation}

Pro-oxidative and pro-inflammatory events in the plasma have a strong impact on the intracellular milieu. $\mathrm{H}_{2} \mathrm{O}_{2}$ causes a cascade of intracellular events resulting in the liberation of NF- $\kappa$ B from its inhibitor ІкB [46]. NF-кB can be activated via several other pathways, as reviewed by MacDonald and co-workers [40]. For example, TNF- $\alpha$, one of the primary mediators of the innate immune system, binds to its specific receptor (TNFR), which leads to the activation of multi-component protein kinase ( $\mathrm{I} k B$ kinase), ІкB phosphorylation, and NF- $\mathrm{kB}$ release and translocation into the nucleus [40] Clearly NF- $\mathrm{kB}$ has a special place in sepsis development. In an animal study lipopolysaccharide administration resulted in NF- $\mathrm{kB}$ activation in several organs [47]. Two different research groups have reported that NF- $\mathrm{kB}$ activity is significantly higher in septic non-survivors in comparison to controls and survivors and that NF- $\mathrm{kB}$ activity predicts sepsisrelated mortality $[48,49]$. Finally, encouraging results of clinical trials with activated protein $C$ could be at least partially attributed to its ability to block the expression of NF-KB-regulated genes [50].

NF- $k B$ binds to DNA to enable the initiation of the transcription process of a number of genes, two of them encoding redox-active enzymes: inducible $\mathrm{NO}$ synthase (iNOS) [51] and cyclooxygenase (COX)-2, which generates ${ }^{\circ} \mathrm{O}_{2}$ ' as a by-product [52]. It is noteworthy that iNOS expression can be stimulated by hypoxia inducible factor-1, which is also activated by ROS [53]. In contrast to constitutively expressed endothelial NOS, which produces local $\mathrm{NO}$ concentrations in the nanomolar range, iNOS has been estimated to produce $\mathrm{NO}$ in the micromolar range $[54,55]$. The role of iNOS expression in non-septic infections is to induce $\mathrm{NO}$-mediated vasodilatation, thus enabling adequate circulation in the affected areas and normal cardiac function [56]. However, over-expression of iNOS in sepsis affects normal cellular functions [57]. Pertinent to such dual (patho)physiological roles of iNOS in sepsis, it has been demonstrated in two separate studies that iNOS-deficient animals exposed to endotoxin show lower cardiac output [58] but have improved survival [59] in comparison to control subjects.

Over-expression of iNOS occurs early in sepsis $[54,60]$, taking place in nearly all the vital organs [61]. Patients with sepsis show increased ${ }^{\circ} \mathrm{NO}$ production and elevated nitrite and nitrate levels, which have been correlated with the severity of illness [62]. The negative role of iNOS in sepsis is also indicated by the fact that the administration of the iNOS substrate arginine results in a poorer outcome in sepsis [63]. The mechanism that makes 'NO production deleterious to cells seems to be related to protein nitrosylation and nitration, which can modulate the function of various enzymes and ion channels as well as different signalling pathways [23]. In addition, ${ }^{-N O}$ efflux from cells and a substantial increase in the $\mathrm{NO}$ level in plasma may occur. ${ }^{\circ} \mathrm{NO}$ converts haemoglobin to methaemoglobin (MetHb), which leads to increased rigidity of red blood cells (RBCs) and RBC lysis [64]. Another potential cause of RBC lysis in sepsis is the ability of $\mathrm{HOCl}$ to induce membrane-pore formation in RBCs [65]. RBC lysis results in the release of MetHb into the plasma [64], reflecting the severity of sepsis [66]. An increased level of free MetHb in the plasma may have several propagating effects on sepsis development: (i) it leads to increased availability of iron to pathogens, which may fuel their proliferation [67]; (ii) it has pro-inflammatory effects by stimulating interleukins (IL-6 and IL-8) and E-selectin [68]; and (iii) MetHb is an activator of NF- $\kappa B$ [64], which may lead to further iNOS expression, thus closing a ${ }^{N} \mathrm{NO}$-generating loop (Figure 2 ).

\section{Intracellular superoxide generation}

Septic insult significantly increases intracellular ${ }^{\circ} \mathrm{O}_{2}{ }_{2}^{-}$[69]. This is substantiated by the high activity of superoxide dismutase (SOD) in sepsis [22,27]. There are several intracellular ${ }^{\circ} \mathrm{O}_{2}$ - generators implicated in sepsis: NADPH oxidase, COX-2, xanthine oxidase and the electron transfer chain (ETC) in mitochondria. The entry of ROS from the plasma into the cell can initiate the expression of NADPH oxidase and COX-2 [40,52,70]. The early rise in ${ }^{\circ} \mathrm{O}_{2}$ production in endothelial cells in sepsis is abolished by NADPH oxidase inhibitors [69], while the inhibition of 


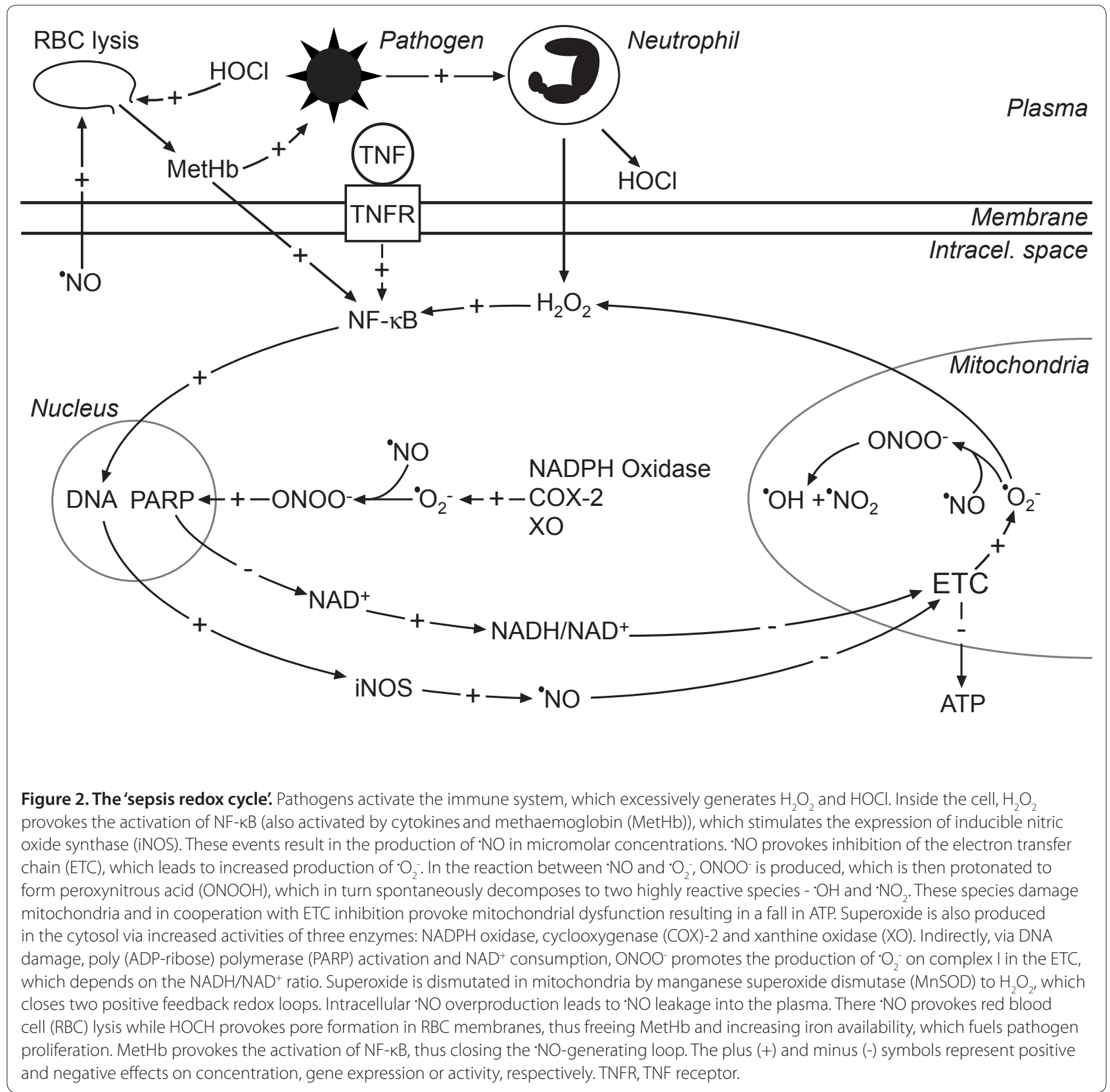

$\mathrm{COX}-2$ leads to a decrease in the production of ONOO(an ${ }^{\circ} \mathrm{O}_{2}$ - derivative; Figure 1, reaction 3 ) in sepsis models $[52,71]$. At the later stages of sepsis development these two enzymes are accompanied by increased xanthine oxidase activity $[72,73]$ and pronounced production of $\cdot \mathrm{O}_{2}$ - on the mitochondrial inner membrane.

The generation of ${ }^{\prime} \mathrm{O}_{2}$ - in mitochondria is related to the leakage of electrons out of the respiratory chain into $\mathrm{O}_{2}$. Such production is intrinsic to aerobic organisms, with up to $2 \%$ of $\mathrm{O}_{2}$ in mammalian mitochondria reduced to ' $\mathrm{O}_{2}^{-}$under physiological conditions [74]. The production is pronounced if the ETC is inhibited or uncoupled [74] as is the case under septic conditions. It has been documented that ${ }^{\circ} \mathrm{NO}$ actively inhibits mitochondrial respiration under sepsis-modelling conditions [75] and that such effects can be diminished by applying an iNOS inhibitor [76]. Fredriksson and co-authors [22] reported a significant decrease in the activity of complex I (the main site of ${ }^{\circ} \mathrm{O}_{2}$ - production in the ETC [74]) in the muscles of septic patients. Finally, a very recent study noted ETC uncoupling in severe sepsis and septic shock, the response being most pronounced in non-survivors [77]. In mitochondria, ${ }^{\circ} \mathrm{O}_{2}$ ' is dismutated by $\mathrm{MnSOD}$ to $\mathrm{H}_{2} \mathrm{O}_{2}$, which enters the cytosol to close the redox loop (Figure 2). 


\section{Peroxynitrite production and its effects}

The interaction between ${ }^{\circ} \mathrm{NO}$ and ${ }^{\circ} \mathrm{O}_{2}$ - plays a fundamental role in cell and organ failure [78]. Superoxide reacts with $\mathrm{NO}$ at a slightly faster rate than with SOD so when the level of $\mathrm{NO}$ is in the high nanomolar or micromolar range $\mathrm{NO}$ may outcompete SOD and react with ${ }^{\circ} \mathrm{O}_{2}^{-}$to generate $\mathrm{ONOO}^{-}$[79] (Figure 1 , reaction 3 ), which is capable of inhibiting enzyme and membrane functions [23]. In particular, $\mathrm{ONOO}^{-}$is responsible for decreased activity of the $\mathrm{H}_{2} \mathrm{O}_{2}$-removing enzyme glutathione peroxidase in sepsis [80]. The relevance of this interaction in sepsis is demonstrated by the fact that selenium, which is crucial for glutathione peroxidase metabolism, shows clinical benefits in sepsis treatment $[25,80]$.

The most important effects of $\mathrm{ONOO}^{-}$in sepsis are exerted indirectly on mitochondria. It causes DNA singlestrand breakage in the nucleus, which signals poly(ADPribose) polymerase (PARP) to be activated. PARP catalyses the cleavage of $\mathrm{NAD}^{+}$, which leads to a decrease in the $\mathrm{NAD}^{+}$level and to an increase in the NADH/NAD ${ }^{+}$ ratio $[54,81]$. A high $\mathrm{NADH} / \mathrm{NAD}^{+}$ratio is known to raise $\cdot \mathrm{O}_{2}{ }^{-}$production on the mitochondrial complex I [74]. It appears that the $\mathrm{ONOO}^{-}$-provoked increase in ${ }^{\circ} \mathrm{O}_{2}^{-}$production on complex I represents the third major event in sepsis following the immune system-generated oxidative burst and iNOS over-expression. In vitro studies have shown that PARP activation causes energy depletion and cellular injury, while pharmacological inhibition of PARP improves the response of mitochondria to ONOOchallenge [81]. In addition, PARP inhibitors have been shown to diminish sepsis-provoked mitochondrial impairment [56]. The importance of the ONOO-/PARP/NAD ${ }^{+} /$ complex I sequence of events in sepsis is illustrated by the fact that PARP-deficient mice with sepsis show improved survival, while the administration of PARP inhibitors is beneficial in a porcine model of sepsis $[82,83]$. Finally, Khan and co-workers [84] have shown that the application of liposomal $\mathrm{NAD}^{+}$on immunostimulated cells (modelling sepsis), leading to a decreased $\mathrm{NADH} / \mathrm{NAD}^{+}$ratio, prevents diminished consumption of $\mathrm{O}_{2}$ provoked by $\mathrm{ONOO}^{-}$.

As in the case of ${ }^{\circ O}$-promoted ${ }^{\circ} \mathrm{O}_{2}$ - production in mitochondria, $\mathrm{ONOO}^{-}$-provoked generation of ${ }^{\circ} \mathrm{O}_{2}$ - results in increased mitochondrial $\mathrm{H}_{2} \mathrm{O}_{2}$, which leaks from mitochondria to further promote NF- $\mathrm{kB}$ activation, thus closing another redox loop (Figure 2). In line with this, application of the ONOO-decomposition catalyst FeTPPS has been reported to reduce NF- $\mathrm{KB}$ activation in endotoxaemic mice [85].

\section{Mitochondrial dysfunction}

Mitochondria are specifically targeted by highly reactive products of $\mathrm{ONOO}^{-}$decomposition - ${ }^{\circ} \mathrm{OH}$ and ${ }^{-} \mathrm{NO}_{2}$ [23] (Figure 1, reaction 4). The hydroxyl radical non-selectively damages membranes, proteins and DNA [24] while $\cdot \mathrm{NO}_{2}$ binds to proteins leading to increased susceptibility to protease activity [23]. Pertinent to this, research regarding mitochondrial structure after lipopolysaccharide insult revealed oxidative stress and pronounced mitochondrial DNA damage [16,20]. In combination with ETC inhibition, oxidative modifications lead to mitochondrial dysfunction, which is intimately linked to a depleted cellular ATP pool and an energy deficit characteristic of sepsis (Table 3).

Dysfunctional mitochondria show increased susceptibility to mitoptosis. Morphological changes characteristic of mitoptosis have been documented in a feline model of acute endotoxaemia [86], while a decrease in mitochondrial content has been observed in patients with prolonged septic conditions [22]. A lower number of mitochondria may further compromise energy balance. Together, a fall in ATP concentration and oxidative stress exerted on mitochondrial metabolites lead to mitochondrial permeability transition pore opening with eventual organelle swelling and cytochrome c release. Once in the cytoplasm, cytochrome c can bind to apoptotic protease activating factor 1 (APAF-1) and thus activate caspase-9, which in turn activates caspase- 3 and -7 , culminating in apoptosis in some cell types. Anti-oxidant treatment can prevent mitochondrial swelling and cytochrome c release, pinpointing the role of ROS in mitochondrial dysfunction [87]. Mitochondrial dysfunction represents the fourth and final major redox event in the pathogenesis of sepsis.

Patients typically die of sepsis days to weeks after the onset of the initial infection and in some cases even after the original infection has been eradicated $[1,2]$. Interestingly 10 to $40 \%$ of sepsis patients show negative cultures $[1,2]$. At the later stages of sepsis the immune system is in a hypoactive mode. Therefore, the plasma oxidative burst can no longer be directly responsible for cell/organ dysfunction [7]. These facts imply that infection could, under specific conditions, activate a self-sustaining and self-promoting redox cycle. Instead of shutting down upon pathogen eradication or in the immune hypoactive stage the 'sepsis redox cycle' continues to drain energy and prevents normal function from being re-established due to several positive feedback loops (Figure 2), even when there is no further inflow of reactive species from plasma. It is important to note that in the 'sepsis redox cycle' $\mathrm{H}_{2} \mathrm{O}_{2}$ crosses both cellular and mitochondrial membranes. This transport is facilitated by aquaporin-8 [88]. Interestingly, aquaporin- 8 is down-regulated in sepsis [89], which may be a mechanism of defence targeted at stopping or slowing down the cycle. The pathophysiological redox profile of one cell can spill over to surrounding tissue, due to the ability of $\mathrm{H}_{2} \mathrm{O}_{2}$ and $\mathrm{NO}$ to cross membranes, thus leading to organ failure. 
Table 3. The level of ATP in sepsis

\begin{tabular}{|c|c|c|}
\hline Subjects & Results & Reference \\
\hline Critically ill septic patients and healthy subjects undergoing elective surgery & $\begin{array}{l}\text { ATP (nmol/mg dry weight) in skeletal muscle biopsies: } \\
\text { Controls (8): } 12.5 \text { (9.7 to } 13.7) \\
\text { Survivors (12):15.8 (12.1 to 18.6) } \\
\text { Non-survivors (9): } 7.6(6.6 \text { to } 10.0)(P<0.001)\end{array}$ & [21] \\
\hline Human umbilical vein endothelial cells incubated with healthy or septic sera & $\begin{array}{l}\text { ATP (nmol/L) in the cells exposed to the serum of: } \\
\text { Controls: } 13.5 \pm 1.9 \\
\text { Septic shock patients: } 6.7 \pm 1.2(P<0.01)\end{array}$ & [76] \\
\hline Murine model of endotoxaemia (LPS-induced) & $\begin{array}{l}\text { ATP ( } \mu \mathrm{mol} / \mathrm{g} \text { wet weight) in liver: } \\
\text { Controls: } 3.51 \pm 0.21 \\
\text { Endotoxaemic: } 3.00 \pm 0.13(P<0.05)\end{array}$ & [122] \\
\hline
\end{tabular}

LPS, lipopolysaccharide.

\section{Polymorphisms of redox-relevant genes and sepsis}

The question why the activation of the immune system in some patients leads to sepsis and in others does not remains unresolved. On the basis of studies in identical twins genetic factors have been implicated in the determination of susceptibility to death from infections [90]. It seems that specific gene polymorphisms of some redoxactive enzymes are more frequent in patients with sepsis and other related conditions in comparison to the general population (Table 4). However, the exact role of gene polymorphisms in sepsis susceptibility and sepsis development, progression and outcome remains to be further elucidated.

\section{Redox therapy in sepsis}

Sepsis is treated by controlling the source of infection, administering antimicrobial therapy, assuring hemodynamic support with fluid resuscitation and vasopressor drugs, inducing sedation or analgesia as needed and by other supportive therapies [91]. Despite these interventions, about one-third of all septic patients die before leaving hospital $[1,2]$. Therefore, the development of additional treatment approaches, such as anti-oxidative therapy, is a research topic of urgent priority.

Although many promising results have been obtained from animal models, believable benefit from anti-oxidant application in sepsis has rarely been translated into success in human clinical trials [92]. This may be explained by several reasons. Animal models of sepsis do not completely recapitulate the human disease or involve identical care delivered to human sepsis patients [93-95]. The onset and progression of sepsis to multi-organ failure occurs over days to weeks whereas in most animal models these processes are much faster, occurring within hours to days. Animal models of sepsis almost exclusively use young animals, which mimic the physiology of a young human. The pitfall here is that epidemiologic studies show that the older human population is more susceptible to sepsis. Moreover, in contrast to animal models, patients with sepsis commonly have co-morbidities [95]. Finally, models and clinical sepsis show very different cytokine dynamics $[93,94]$. It should be stressed that therapeutic studies on animals sometimes involve the application of high doses of anti-oxidants exceeding recommended human allowances that clinical researchers are reluctant to use in trials. In addition, animal studies frequently employ early application of therapy (or pretreatment), which is often not the case with clinical sepsis. Some clinical trials do not take into account all the main principles of anti-oxidative therapy. Halliwell and Gutteridge [23] made a list of questions that generally should be answered preceding the use of an anti-oxidant in humans: (i) Is it non-toxic? (ii) Which biomolecules will the anti-oxidant protect, and are such molecules implicated in the pathogenesis of the disease? (iii) How does the anti-oxidant work - by scavenging reactive species, increasing endogenous defence or by repairing the damage? (iv) Can the anti-oxidant-derived products cause damage? (v) Does the anti-oxidant interfere with redox signalling? Kohen and Nyska [96] sublimed the principles of anti-oxidant therapy as follows: 'Taking into consideration the high reactivity of ROS, their short life span, their continuous production in close proximity to biological targets and their ability to be modified into other more reactive species, one realises that, in order to cope with these deleterious metabolites, the anti-oxidant should be administered to the body continuously, in high concentrations and targeted to the biological site susceptible to oxidative damage.' Pertinent to this and the mechanism proposed here, it is clear that a redox approach in sepsis treatment should be targeted at the specific steps in the pathogenesis. For example, very promising effects of therapies targeting dysfunctional mitochondria have been reviewed recently by Dare and colleagues [16] and Galley [20].

Targeted delivery of anti-oxidants into intracellular space is limited by mechanisms regulating the level of reducing agents in order to maintain normal functioning of signalling pathways that involve reactive species [97]. Therefore, even if long-term supplementation raises blood anti-oxidants, it will have a limited effect on intracellular levels or redox status [97]. Hence, the majority of 
Table 4. Polymorphisms of genes involved in redox regulation that are implicated in sepsis and related conditions

\begin{tabular}{|c|c|c|c|c|c|}
\hline Gene & Polymorphism & Effect of polymorphism & Population & Genotypes & Reference \\
\hline $\begin{array}{l}\text { p22-PHOX (NADPH } \\
\text { oxidase subunit) }\end{array}$ & C242T & $\begin{array}{l}\text { Tallele is associated with } \\
\text { higher plasma levels of } \\
\text { nitrotyrosine (circulating } \\
\text { biomarker of } \mathrm{O}_{2} \text { - and } \cdot \mathrm{NO} \\
\text { generation) }\end{array}$ & $\begin{array}{l}\text { Patients with acute renal } \\
\text { failure (200) }\end{array}$ & $\begin{array}{l}\text { T-allele carrier state was associated } \\
\text { with 2.1-fold higher odds for dialysis } \\
\text { requirement or hospital death }(P<0.01)\end{array}$ & [123] \\
\hline MNSOD & Ala9Val & $\begin{array}{l}\text { Valine variant is associated } \\
\text { with decreased intra- } \\
\text { mitochondrial transport of } \\
\text { MnSOD }\end{array}$ & $\begin{array}{l}\text { Healthy subjects (100) and } \\
\text { patients with sepsis (40) }\end{array}$ & $\begin{array}{l}\text { A/A: } 20 \% \text { (frequency in control group) and } \\
27.5 \% \text { (in sepsis) } \\
\text { VN: } 36 \% \text { and } 10 \% \\
\text { AN: } 44 \% \text { and } 62.5 \%\end{array}$ & [124] \\
\hline eNOS & G894T & $\begin{array}{l}\text { Tallele is related to low levels } \\
\text { of eNOS activity }\end{array}$ & $\begin{array}{l}\text { Patients with Escherichia coli } \\
\text { bacteraemia (42) }\end{array}$ & $\begin{array}{l}\text { Carriage of the Tallele was associated } \\
\text { with low mean arterial pressure and high } \\
\text { Sequential Organ Failure Assessment score }\end{array}$ & [125] \\
\hline $\begin{array}{l}\text { MPO (gene } \\
\text { promoter) }\end{array}$ & G-129A & $\begin{array}{l}\text { A allele causes loss of } \\
\text { transcriptional factor binding } \\
\text { site and lower amount of MPO } \\
\text { in cytoplasmatic granules }\end{array}$ & $\begin{array}{l}\text { Patients that underwent } \\
\text { chemotherapy (136) or } \\
\text { autologous stem cell } \\
\text { transplantation (113) }\end{array}$ & $\begin{array}{l}\text { Chemotherapy: } \\
\text { GG: } 11 \% \text { developed sepsis } \\
\text { GA: } 17 \% \text { developed sepsis } \\
\text { ASCT: } \\
\text { GG: } 7 \% \text { developed sepsis } \\
\text { GA: } 25 \% \text { developed sepsis }\end{array}$ & [126] \\
\hline $\begin{array}{l}\text { NRF2 (gene } \\
\text { promoter) }\end{array}$ & $C-617 A$ & $\begin{array}{l}\text { A allele presents less } \\
\text { transcriptional activity than } \\
\text { Callele }\end{array}$ & $\begin{array}{l}\text { Humans with major trauma } \\
\text { (164) }\end{array}$ & $\begin{array}{l}\text { Carriage of the } A \text { allele was related to a } \\
\text { greater risk of acute lung injury }(P=0.021)\end{array}$ & {$[127]$} \\
\hline $\begin{array}{l}\text { HMOX1 (gene } \\
\text { promoter) }\end{array}$ & $(\mathrm{GT})_{n}$ & $\begin{array}{l}\text { Longer }(\mathrm{GT})_{n} \text { repeats in } \\
\text { the } \mathrm{HMOX} 1 \text { promoter are } \\
\text { associated with higher plasma } \\
\text { HO-1 levels }\end{array}$ & $\begin{array}{l}\text { ICU patients who developed } \\
\text { (437) or did not develop } \\
\text { (1014) acute respiratory } \\
\text { distress syndrome }\end{array}$ & $\begin{array}{l}\text { Longer (GT)n repeats are associated } \\
\text { with reduced acute respiratory distress } \\
\text { syndrome risk }\end{array}$ & {$[128]$} \\
\hline TNF & $\begin{array}{l}\text { TNF1 and TNF2 } \\
\text { allele }\end{array}$ & $\begin{array}{l}\text { TNF2 is associated with } \\
\text { higher levels of inducible and } \\
\text { constitutional TNF }\end{array}$ & $\begin{array}{l}\text { Critically ill infected patients } \\
(112)\end{array}$ & $\begin{array}{l}\text { TNF2 frequency: } \\
\text { General population: } 5 \% \\
\text { Studied group: } 12 \%(P<0.01) \\
\text { Overall mortality: } \\
\text { TNF1/TNF1: } 48 \% \\
\text { TNF1/TNF2: } 62 \% \\
\text { The frequency of septic shock: } \\
\text { TNF1/TNF1: } 34 \% \\
\text { TNF1/TNF2: } 50 \% \\
\text { Mortality in septic shock patients: } \\
\text { TNF1/TNF1: } 62 \% \\
\text { TNF1/TNF2: } 92 \%(P<0.05)\end{array}$ & [129] \\
\hline HIF-1a & С85T & $\begin{array}{l}\text { T variant presents more } \\
\text { transcriptional activity }\end{array}$ & $\begin{array}{l}\text { Patients with acute kidney } \\
\text { injury (241) }\end{array}$ & $\begin{array}{l}\text { T-allele carriers had significantly higher } \\
\text { odds for in-hospital death }(P<0.001)\end{array}$ & [130] \\
\hline
\end{tabular}

eNOS, endothelial NOS; HIF, hypoxia inducible factor; HO-1, haem oxygenase (haem degrading enzyme); MnSOD, manganese superoxide dismutase; MPO, myeloperoxidase ( $\mathrm{HOCl}$ generator).

anti-oxidants perform their actions predominantly in plasma, which may have beneficial effects during the hyper-inflammatory stage of sepsis but are ineffective against the self-sustaining 'sepsis redox cycle' taking place inside the cell. This raises the question of how to overcome refractory mechanisms and help the organism to fight intracellular oxidative stress against its own 'will'. In other words, in conditions related to intracellular oxidative stress, such as sepsis, reducing agents targeted to intracellular space and capable of accumulating inside the cell are needed.

Potential candidates for such an approach are fructose 1,6-(bis)phosphate and ethyl pyruvate, which act as both antioxidants and energy molecules $[98,99]$, and organisms in times of crisis will not reject energy supplies. These compounds have already shown positive effects in sepsis models [100-103], but are yet to be studied in clinical trials. Molecular hydrogen that reacts directly with ROS should also be capable of overcoming the refractory response. Recently, Xie and co-workers [104] reported that $\mathrm{H}_{2}$ inhalation significantly improved the survival rate of septic mice in a concentration- and timedependent manner.

An alternative anti-oxidative approach is to suppress ROS production in mitochondria. It has been shown that maintenance of glucose in blood within the range 4.4 to $6.1 \mathrm{mM}$, instead of the normally higher range of 10.0 to $11.1 \mathrm{mM}$, leads to a decrease in mortality by more than $10 \%$ [105]. We propose that decreased availability of glucose could exert positive effects in sepsis by preventing the production of ${ }^{\circ} \mathrm{O}_{2}$ - on mitochondrial complex I. A lower level of glucose leads to decreased generation of $\mathrm{NADH}$ and hence to a decrease in the NADH/NAD ${ }^{+}$ ratio. Another way to decrease the $\mathrm{NADH} / \mathrm{NAD}^{+}$ratio is 
to apply liposomal $\mathrm{NAD}^{+}$, which has been shown to prevent diminished $\mathrm{O}_{2}$ consumption in mitochondria under septic conditions [84]. As an alternative to feeding complex I, which represents a point of electron leakage and ${ }^{\prime} \mathrm{O}_{2}$ ' production, mitochondrial complex II could be supplemented with succinate in order to bypass ${ }^{\circ} \mathrm{O}_{2}$ - production on complex I and in parallel to maintain normal energy metabolism. Several studies have confirmed positive effects of succinate in sepsis [106-108].

Pertinent to the important role of iNOS and $\mathrm{NO}$ in sepsis-related cell/organ dysfunction, therapeutic strategies capable of decreasing the level of $\mathrm{NO}$ could be beneficial in sepsis. The supplementation of selective iNOS inhibitors, such as aminoguanide, L-NAME and LN6-(1-imminoethyl)lysine, has had positive effects in different sepsis models [109-113]. It is interesting that a clinical trial of the non-selective NOS inhibitor LNMMA in patients with septic shock was terminated early because of increased mortality. Such an adverse effect of high-dose L-NMMA may have resulted from the inhibition of endothelial NOS, whose activity is essential for microvascular homeostasis [114]. In addition to iNOS inhibition, $\mathrm{NO}$ excess can be tackled using "NO scavengers. For example, diethyldithiocarbamate (DDC) demonstrates positive effects in septic shock mice, partially due to the ability of the iron-DDC complex to sequester ${ }^{*} \mathrm{NO}[115]$.

\section{Conclusions}

Organ failure in sepsis is provoked by cellular dysfunction, a process related to pro-oxidative conditions and dysfunctional mitochondria. The oxidative burst performed by the innate immune system is 'transferred' from the plasma into the cell, where it activates the production of ROS and RNS, resulting in non-physiological redox conditions, disturbed redox signalling, oxidative damage of diverse molecules and cellular structures and energy depletion. These events are interconnected in a selfsustaining and self-promoting pathological process named here as the 'sepsis redox cycle', which may result in the total loss of cellular function. Redox therapies targeting specific steps of the 'sepsis redox cycle' have shown some very promising results for sepsis treatment, but require further clinical evaluation. Although it is obvious that sepsis represents a multi-factorial pathophysiology, studies investigating the effects of multi-target therapies are still scarce. We believe that instead of looking for a single 'magic bullet' for sepsis treatment, a multi-component 'magic bullets' therapeutic approach combining different redox agents capable of suppressing specific steps in the pathogenesis of sepsis is clearly the way forward.

Abbreviations

ARE, anti-oxidant response element; COX, cyclooxygenase; ETC, electron transfer chain; $\mathrm{H}_{2} \mathrm{O}_{2}$ hydrogen peroxide; $\mathrm{HOCl}$, hypochlorous acid;
IL, interleukin; iNOS, inducible nitric oxide synthase; MetHb, methaemoglobin; $\mathrm{MnSOD}$, manganese superoxide dismutase; NF, nuclear factor; $\mathrm{NO}$, nitric oxide; $\mathrm{NO}_{2}$, nitrogen dioxide radical; NOS, nitric oxide synthase; Nrf2, nuclear factor E2-related factor $2 ; \mathrm{O}_{2}$; superoxide; $\mathrm{OH}$, hydroxyl radical; ONOO; peroxynitrite; $\cdot \mathrm{OOH}$, hydroperoxyl radical; PARP, poly (ADP-ribose) polymerase; $\mathrm{RBC}$, red blood cell; RNS, reactive nitrogen species; $R O O$, peroxyl radical; ROS, reactive oxygen species; SOD, superoxide dismutase; TNF, tumour necrosis factor.

\section{Competing interests}

The authors declare that they have no competing interests.

\section{Acknowledgements}

Supported by the Ministry of Science, Technology, and Development of the Republic of Serbia grant number OI 173014'Molecular mechanisms of redox signaling in homeostasis, adaptation and pathology' and grant number 43004 This paper is dedicated to the memory of Marica Spasojević, a sepsis victim (1950 to 2000)

\section{Author details}

'Cardiovascular Research Laboratory, Research Centre, Hospital de Clínicas de Porto Alegre, Rua Ramiro Barcelos 2350, Porto Alegre, Brazil. ${ }^{2}$ Institute for Multidisciplinary Research, University of Belgrade, Kneza Višeslava 1, 11000 Belgrade, Serbia. ${ }^{3}$ ChTM, University of Belgrade, Njegoševa 12, PO Box 473, 11001 Belgrade, Serbia.

Published: 14 September 2011

\section{References}

1. Angus DC, Linde-Zwirble WT, Lidicker J, Clermont G, Carcillo J, Pinsky MR: Epidemiology of severe sepsis in the United States: analysis of incidence, outcome and associated costs of care. Crit Care Med 2001, 29:1303-1311.

2. Vincent IL, Sakr Y, Sprung CL, Ranieri VM, Reinhart K, Gerlach H, Moreno R, Carlet J, Le Gall JR, Payen D: Sepsis in European intensive care units: results of the SOAP study. Crit Care Med 2006, 34:344-353.

3. Lever A, Mackenzie I: Sepsis: definition, epidemiology, and diagnosis. BrMed J 2007, 335:879-883.

4. Thomas L: Germs. N Engl J Med 1972, 287:553-555.

5. Bone RC, Balk RA, Cerra FB, Dellinger RP, Fein AM, Knaus WA, Schein RM, Sibbald WJ: Definitions for sepsis and organ failure and guidelines for the use of innovative therapies in sepsis. Chest 1992, 101:1644-1655.

6. Deitch EA: Animal models of sepsis and shock: a review and lessons learned. Shock 1998, 9:1-11.

7. Hotchkiss RS, Karl IE: The pathophysiology and treatment of sepsis. N Engl J Med 2003, 348:138-150.

8. Russell JA: Management of sepsis. NEngl J Med 2006, 355:1699-1713.

9. Annane D, Sebille V, Charpentier C, Bollaert PE, François B, Korach JM, Capellier G, Cohen Y, Azoulay E, Troché G, Chaumet-Riffaud P, Bellissant E: Effect of treatment with low doses of hydrocortisone and fludrocortisone on mortality in patients with septic shock. JAMA 2002, 288:862-871.

10. Docke WD, Randow F, Syrbe U, Krausch D, Asadullah K, Reinke P, Volk HD, Kox W: Monocyte deactivation in septic patients: restoration by IFN-gamma treatment. Nat Med 1997, 3:678-681

11. O'Suilleabhain C, O'Sullivan ST, Kelly JL, Lederer J, Mannick JA, Rodrick ML: Interleukin-12 treatment restores normal resistance to bacterial challenge after burn injury. Surgery 1996, 120:290-296.

12. Hotchkiss RS, Swanson PE, Cobb JP, Jacobson A, Buchman TG, Karl IE: Apoptosis in lymphoid and parenchymal cells during sepsis: findings in normal and T- and B-cell-deficient mice. Crit Care Med 1997, 25:1298-1307.

13. Hotchkiss RS, Swanson PE, Freeman BD, Tinsley KW, Cobb JP, Matuschak GM, Buchman TG, Karl IE: Apoptotic cell death in patients with sepsis, shock, and multiple organ dysfunction. Crit Care Med 1999, 27:1230-1251.

14. Solez K, Morel-Maroger L, Sraer JD: The morphology of "acute tubular necrosis" in man: analysis of 57 renal biopsies and a comparison with the glycerol model. Medicine 1979, 58:362-376.

15. Wheeler AP, Bernard GR: Treating patients with severe sepsis. N Engl J Med 1999, 340:207-214

16. Dare AJ, Phillips ARJ, Hickey AJR, Mittal A, Loveday B, Thompson N, Windsor $J A$ : A systematic review of experimental treatments for mitochondrial dysfunction in sepsis and multiple organ dysfunction syndrome. Free Radic Biol Med 2009, 47:1517-1525.

17. Hayes MA, Timmins AC, Yau EH, Palazzo M, Watson D, Hinds CJ: Oxygen 
transport patterns in patients with sepsis syndrome or septic shock: influence of treatment and relationship to outcome. Crit Care Med 1997, 25:926-936.

18. Van der Meer TJ, Wang H, Fink MP: Endotoxemia causes ileal mucosal acidosis in the absence of mucosal hypoxia in a normodynamic porcine model of septic shock. Crit Care Med 1995, 23:1217-1226.

19. Fink MP: Cytopathic hypoxia: mitochondrial dysfunction as mechanism contributing to organ dysfunction in sepsis. Crit Care Clin 2001, 17:219-237.

20. Galley HF: Bench-to-bedside review: targeting antioxidants to mitochondria in sepsis. Crit Care 2010, 14:230.

21. Brealey D, Brand M, Hargreaves I, Heales S, Land J, Smolenski R, Davies NA Cooper CE, Singer M: Association between mitochondrial dysfunction and severity and outcome of septic shock. Lancet 2002, 360:219-223.

22. Fredriksson K, Hammarqvist F, Strigård K, Hultenby K, Ljungqvist O, Wernerman J, Rooyackers $\mathrm{O}$ : Derangements in mitochondrial metabolism in intercostal and leg muscle of critically ill patients with sepsis induced multiple organ failure. Am J Physiol Endocrinol Metab 2006, 291:E1044-E1050.

23. Halliwell B, Gutteridge JMC: Free Radicals in Biology and Medicine. Oxford: Oxford University Press; 2007.

24. Andrades ME, Ritter C, Dal-Pizzol F: The role of free radicals in sepsis development. Front Biosci 2009, 1:277-287.

25. Berger MM, Chioléro RL: Antioxidant supplementation in sepsis and systemic inflammatory response syndrome. Crit Care Med 2007, 35:S584-S590

26. Crimi E, Liguori A, Condorelli M, Cioffi M, Astuto M, Bontempo P, Pignalosa O, Vietri MT, Molinari AM, Sica V, Della Corte F, Napoli C: The beneficial effects of antioxidant supplementation in enteral feeding in critically ill patients: A prospective, randomized, double-blind, placebo-controlled trial. Anesth Analg 2004, 99:857-863.

27. Ritter C, Andrades ME, Frota Junior ML, Bonatto F, Pinho RA, Polydoro M, Klamt F, Pinheiro CT, Menna-Barreto SS, Moreira JC, Dal-Pizzol F: Oxidative parameters and mortality in sepsis induced by cecal ligation and perforation. Intensive Care Med 2003, 29:1782-1789.

28. Gao XP, Standiford TJ, Rahman A, Newstead M, Holland SM, Dinauer MC, Liu QH, Malik AB: Role of NADPH oxidase in the mechanism of lung neutrophil sequestration and microvessel injury induced by Gram-negative sepsis: studies in p47phox-/- and gp91 phox-/- mice. J Immunol 2002, 168:3974-3982.

29. Babior BM: NADPH oxidase. Curr Opin Immunol 2004, 16:42-47.

30. Cowley HC, Bacon PJ, Goode HF, Webster NR, Jones JG, Menon DK: Plasma antioxidant potential in severe sepsis: a comparison of survivors and nonsurvivors. Crit Care Med 1996, 24:1179-1183.

31. Pascual C, Karzai W, Meier-Hellmann A, Oberhoffer M, Horn A, Bredle D, Reinhart K: Total plasma antioxidant capacity is not always decreased in sepsis. Crit Care Med 1998, 26:705-709.

32. Cherian $\mathrm{S}$, Jameson $\mathrm{S}$, Rajarajeswari C, Helena V, Latha L, Rekha A, Nagamma T, Raju S, Kini PG, Rao A: Oxidative stress in sepsis in children. Indian J Med Res 2007, 125:143-148.

33. Edmond K, Zaidi A: New approaches to preventing, diagnosing, and treating neonatal sepsis. PLoS Med 2010, 7:e1000213.

34. Baltimore RS: Neonatal sepsis: epidemiology and management. Paediatr Drugs 2003, 5:723-740

35. Winterbourn CC: Biological reactivity and biomarkers of the neutrophil oxidant, hypochlorous acid. Toxicology 2002, 181:223-227.

36. Adibhatla RM, Hatcher JF: Lipid oxidation and peroxidation in CNS health and disease: From molecular mechanisms to therapeutic opportunities. Antioxid Redox Signal 2010, 12:125-169.

37. Rees MD, Whitelock JM, Malle E, Chuang CY, lozzo RV, Nilasaroya A, Davies MJ: Myeloperoxidase-derived oxidants selectively disrupt the protein core of the heparan sulfate proteoglycan perlecan. Matrix Biol 2010, 29:63-73.

38. Park SY, Shin SW, Lee S, Park J: Hypochlorous acid-induced modulation of cellular redox status in HeLa cells. Arch Pharm Res 2008, 31:905-910.

39. D'Autréaux B, Toledano MB: ROS as signalling molecules: mechanisms that generate specificity in ROS homeostasis. Nat Rev 2007, 8:813-824

40. Macdonald J, Galley HF, Webster NR: Oxidative stress and gene expression in sepsis. Br J Anaesth 2003, 90:221-232.

41. Hur W, Gray NS: Small molecule modulators of antioxidant response pathway. Curr Opin Chem Biol 2011, 15:162-173.

42. Jung KA, Kwak MK: The Nrf2 system as a potential target for the development of indirect antioxidants. Molecules 2010, 15:7266-7291.

43. Thimmulappa RK, Lee H, Rangasamy T, Reddy SP, Yamamoto M, Kensler TW,
Biswal S: Nrf2 is a critical regulator of the innate immune response and survival during experimental sepsis. J Clin Invest 2006, 116:984-995.

44. Kong X, Thimmulappa R, Kombairaju P, Biswal S: NADPH oxidase-dependent reactive oxygen species mediate amplified TLR4 signaling and sepsisinduced mortality in Nrf2-deficient mice. J Immunol 2010, 185:569-577.

45. Deng Z, Pardi R, Cheadle W, Xiang X, Zhang S, Shah SV, Grizzle W, Miller D, Mountz J, Zhang HG: Plant homologue constitutive photomorphogenesis 9 (COP9) signalosome subunit CSN5 regulates innate immune responses in macrophages. Blood 2011, 117:4796-4804.

46. Barnes PJ: Nuclear factor-KB. Int J Biochem Cell Biol 1997, 29:867-870

47. Blackwell TS, Yull FE, Chen C-L, Venkatakrishnan A, Blackwell TR, Hicks DJ, Lancaster LH, Christman JW, Kerr LD: Multiorgan nuclear factor kappa B activation in a transgenic mouse model of systemic inflammation. $\mathrm{Am} J$ Respir Crit Care Med 2000, 162:1095-1101.

48. Arnalich F, Garcia-Palomero E, López J, Jiménez M, Madero R, Renart J, Vázquez JJ, Montiel C: Predictive value of nuclear factor kB activity and plasma cytokine levels in patients with sepsis. Infect Immun 2000, 68:1942-1945.

49. Böhrer H, Qiu F, Zimmermann T, Zhang Y, Jllmer T, Männel D, Böttiger BW, Stern DM, Waldherr R, Saeger HD, Ziegler R, Bierhaus A, Martin E, Nawroth PP: Role of NF-kB in the mortality of sepsis. J Clin Invest 1997, 100:972-985.

50. Bernard GR, Vincent JL, Laterre PF, La Rosa SP, Dhainaut JF, Lopez-Rodriguez A, Steingrub JS, Garber GE, Helterbrand JD, Ely EW, Fisher CJ Jr: Efficacy and safety of recombinant human activated protein c for severe sepsis. N Engl J Med 2001, 344:699-709.

51. Nam NH: Naturally occurring NF-kappaB inhibitors. Mini Rev Med Chem 2006, 6:945-951.

52. Virdis A, Colucci R, Fornai M, Blandizzi C, Duranti E, Pinto S, Bernardini N, Segnani C, Antonioli L, Taddei S, Salvetti A, Del Tacca M: Cyclooxygenase-2 inhibition improves vascular endothelial dysfunction in a rat model of endotoxic shock: Role of inducible nitric-oxide synthase and oxidative stress. J Pharmacol Exp Therapeut 2005, 312:945-953.

53. Wartenberg M, Hoffmann E, Schwindt H, Grunheck F, Petros J, Arnold JR, Hescheler J, Sauer H: Reactive oxygen species-linked regulation of the multidrug resistance transporter P-glycoprotein in Nox-1 overexpressing prostate tumor spheroids. FEBS Lett 2005, 579:4541-4549.

54. Lange M, Connelly R, Traber DL, Hamahata A, Nakano Y, Esechie A, Jonkam C, von Borzyskowski S, Traber LD, Schmalstieg FC, Herndon DN, Enkhbaatar P. Time course of nitric oxide synthases, nitrosative stress, and poly(ADP ribosylation) in an ovine sepsis model. Crit Care 2010, 14:R129.

55. Moncada S, Palmer R, Higgs E: Nitric oxide-physiology, pathophysiology, and pharmacology. Pharm Rev 1991, 43:109-142.

56. Belcher E, Mitchell J, Evans T: Myocardial dysfunction in sepsis: no role for NO? Heart 2002, 87:507-509.

57. Bruins MJ, Lamers WH, Meijer AJ, Soeters PB, Deutz NE: In vivo measurement of nitric oxide production in porcine gut, liver and muscle during hyperdynamic endotoxaemia. Br J Pharmacol 2002, 137:1225-1236.

58. Nicholson SC, Hahn RT, Grobmyer SR, Brause JE, Hafner A, Potter S, Devereux RB, Nathan CF: Echocardiographic and survival studies in mice undergoing endotoxic shock: effects of genetic ablation of inducible nitric oxide synthase and pharmacologic antagonism of platelet-activating factor. J Surg Res 1999, 86:198-205.

59. Wei XQ Charles IG, Smith A, Ure J, Feng GJ, Huang FP, Xu D, Muller W, Moncada S, Liew FY: Altered immune responses in mice lacking inducible nitric oxide synthase. Nature 1995, 375:408-411.

60. Yin GQ, Du KH, Gu FR, Fang ZX, Tang JQ, Zhong B, Zhu XY, Wu YW, Lu CP: Early-phase endotoxic shock-induced myocardial injury increases iNOS and selectin expression in macaque primate. Heart Lung Circ 2007 16:85-92.

61. Sato K, Miyakawa K, Takeya M, Hattori R, Yui Y, Sunamoto M, Ichimori Y, Ushio Y, Takahashi K: Immunohistochemical expression of inducible nitric oxide synthase (iNOS) in reversible endotoxic shock studied by a novel monoclonal antibody against rat iNOS. J Leukoc Biol 1995, 57:36-44.

62. Evans $\mathrm{T}$, Carpenter A, Kinderman $\mathrm{H}$, Cohen J: Evidence of increased nitric oxide production in patients with the sepsis syndrome. Circ Shock 1993, 41:77-81.

63. Vincent $\mathrm{JL}$ : Metabolic support in sepsis and multiple organ failure: more questions than answers. Crit Care Med 2007, 35:5436-S440

64. Umbreit J: Methemoglobin - it's not just blue: a concise review. Am J Hematol 2007, 82:134-144.

65. Zavodnik LB, Zavodnik IB, Lapshyna EA, Buko VU, Bryszewska MJ: 
Hypochlorous acid-induced membrane pore formation in red blood cells. Bioelectrochemistry 2002, 58:157-161

66. Schuerholz T, Irmer J, Simon TP, Reinhart K, Marx G: Methemoglobin level as an indicator for disease severity in sepsis. Crit Care 2008, 12(Suppl 2):P448.

67. Bullen J, Griffiths E, Rogers H, Ward G: Sepsis: the critical role of iron. Microbes Infect 2000, 2:409-415.

68. Liu X, Spolarics Z: Methemoglobin is a potent activator of endothelial cells by stimulating IL- 6 and IL- 8 production and E-selectin membrane expression. Am J Physiol Cell Physiol 2003, 285:C1036-C1046.

69. Wu F, Schuster DP, Tyml K, Wilson JX: Ascorbate inhibits NADPH oxidase subunit p47phox expression in microvascular endothelial cells. Free Radic Biol Med 2007, 42:124-131.

70. Jacobi J, Kristal B, Chezar J, Shaul SM, Sela S: Exogenous superoxide mediates pro-oxidative, proinflammatory, and procoagulatory changes in primary endothelial cell cultures. Free Radic Biol Med 2005, 39:1238-1248.

71. Hocherl K, Dreher F, Kurtz A, Bucher M: Cyclooxygenase-2 inhibition attenuates lipopolysaccharide-induced cardiovascular failure. Hypertension 2002, 40:947-953.

72. Devrim E, Avci A, Ergüder IB, Karagenç N, Külah B, Durak I: Activities of xanthine oxidase and superoxide dismutase enzymes in rat intestinal tissues in sepsis. J Trauma 2008, 64:733-735.

73. Luchtemberg MN, Petronilho F, Constantino L, Gelain DP, Andrades M, Ritter C, Moreira JC, Streck EL, Dal-Pizzol F: Xanthine oxidase activity in patients with sepsis. Clin Biochem 2008, 41:1186-1190.

74. Murphy MP: How mitochondria produce reactive oxygen species. Biochem J 2009, 417:1-13.

75. Davies NA, Cooper CE, Stidwell R, Singer M: Inhibition of mitochondrial respiration during early stage sepsis. Adv Exp Med Biol 2003, 530:725-736.

76. Boulos M, Astiz ME, Barua RS, Osman M: Impaired mitochondrial function induced by serum from septic shock patients is attenuated by inhibition of nitric oxide synthase and poly (ADP-ribose) synthase. Crit Care Med 2003, 31:353-358

77. Sjövall F, Morota S, Hansson MJ, Friberg H, Gnaiger E, Elmér E: Temporal increase of platelet mitochondrial respiration is negatively associated with clinical outcome in patients with sepsis. Crit Care 2010, 14:R214.

78. Hare JM: Nitroso-redox balance in the cardiovascular system. N Engl J Med 2004, 351:2112-2114.

79. Li JM, Shah AM: Endothelial cell superoxide generation: regulation and relevance for cardiovascular pathophysiology. Am J Physiol Regul Integr Comp Physiol 2004, 287:R1014-1030.

80. Angstwurm MWA, Schottdorf J, Schopohl J, Gaertner R: Selenium replacement in patients with severe systemic inflammatory response syndrome improves clinical outcome. Crit Care Med 1999, 27:1807-1813.

81. Szabó C, Cuzzocrea S, Zingarelli B, O'Connor M, Salzman AL: Endothelial dysfunction in a rat model of endotoxic shock. Importance of the activation of poly (ADP-ribose) synthetase by peroxynitrite. J Clin Invest 1997, 100:723-735

82. Soriano FG, Liaudet L, Szabó E, Virág L, Mabley JG, Pacher P, Szabó C: Resistance to acute septic peritonitis in poly(ADP-ribose) polymerase-1deficient mice. Shock 2002, 17:286-292.

83. Goldfarb RD, Marton A, Szabó E, Virág L, Salzman AL, Glock D, Akhter I, McCarthy R, Parrillo JE, Szabó C: Protective effect of a novel, potent inhibitor of poly(adenosine $5^{\prime}$-diphosphate-ribose) synthetase in a porcine model of severe bacterial sepsis. Crit Care Med 2002, 30:974-980.

84. Khan AU, Delude RL, Han YY, Sappington PL, Han X, Carcillo JA, Fink MP: Liposomal $\mathrm{NAD}^{+}$prevents diminished $\mathrm{O}_{2}$ consumption by immunostimulated Caco-2 cells. Am J Physiol Lung Cell Mol Physiol 2002, 282:L1082-L1091.

85. Lush CW, Cepinskas G, Kvietys PR: Regulation of intestinal nuclear factorkappaB activity and E-selectin expression during sepsis: a role for peroxynitrite. Gastroenterology 2003, 124:118-128.

86. Crouser ED, Julian MW, Blaho DV, Pfeiffer DR: Endotoxin-induced mitochondrial damage correlates with impaired respiratory activity. Crit Care Med 2002, 30:276-284

87. Zapelini PH, Rezin GT, Cardoso MR, Ritter C, Klamt F, Moreira JC, Streck EL, Dal-Pizzol F: Antioxidant treatment reverses mitochondrial dysfunction in a sepsis animal model. Mitochondrion 2008, 8:211-218.

88. Bienert GP, Møller ALB, Kristiansen KA, Schulz A, Møller IM, Schjoerring JK, Jahn TP: Specific aquaporins facilitate the diffusion of hydrogen peroxide across membranes. J Biol Chem 2007, 282:1183-1192.

89. Lehmann GL, Carreras FI, Soria LR, Gradilone SA, Marinelli RA: LPS induces the
TNF-a-mediated downregulation of rat liver aquaporin-8: role in sepsisassociated cholestasis. Am J Physiol Gastrointest Liver Physiol 2008, 294:G567-G575.

90. Sørensen TIA, Nielsen GG, Andersen PK, Teasdale TW: Genetic and environmental influences on premature death in adult adoptees. $N$ Engl J Med 1988, 318:727-732.

91. Dellinger RP, Levy MM, Carlet JM, Bion J, Parker MM, Jaeschke R, Reinhart K, Angus DC, Brun-Buisson C, Beale R, Calandra T, Dhainaut JF, Gerlach H, Harvey M, Marini JJ, Marshall J, Ranieri M, Ramsay G, Sevransky J, Thompson BT, Townsend S, Vender JS, Zimmerman JL, Vincent JL: Surviving sepsis campaign: international guidelines for management of severe sepsis and septic shock. Intensive Care Med 2008, 34:17-60.

92. Mishra V: Oxidative stress and role of antioxidant supplementation in critical illness. Clin Lab 2007, 53:199-209.

93. Buras JA, Holzmann B, Sitkovsky M: Animal models of sepsis: setting the stage. Nat Rev Drug Discov 2005, 4:854-865.

94. Rittirsch D, Hoesel LM, Ward PA: The disconnect between animal models of sepsis and human sepsis. J Leukoc Biol 2007, 81:137-143.

95. Zanotti-Cavazzoni SL, Goldfarb RD: Animal models of sepsis. Crit Care Clin 2009, 25:703-719.

96. Kohen R, Nyska A: Oxidation of biological systems: oxidative stress phenomena, antioxidants, redox reactions, and methods for their quantification. Toxicol Pathol 2002, 30:620-650.

97. Lane N: A unifying view of aging and disease: the double-agent theory. J Theor Biol 2003, 225:531-540

98. Spasojević I, Bajić A, Jovanović K, Spasić M, Andjus P: Protective role of fructose in the metabolism of astroglial $\mathrm{C} 6$ cells exposed to hydrogen peroxide. Carbohydr Res 2009, 344:1676-1681.

99. Fink MP: Ethyl pyruvate: a novel treatment for sepsis. Curr Drug Targets 2007, 8:515-518

100. Yin H, Jin X, Gong Q, Yang H, Hu LY, Gong F, Zhu J: Fructose-1,6-diphosphate attenuates acute lung injury induced by lipopolysaccharide in mice. Int Immunopharmacol 2008, 8:1842-1847.

101. Nunes FB, Simoes Pires MG, Farias Alves Filho JC, Wächter PH, Rodrigues De Oliveira J: Physiopathological studies in septic rats and the use of fructose 1,6-bisphosphate as cellular protection. Crit Care Med 2002, 30:2069-2074.

102. de Mello RO, Lunardelli A, Caberlon E, de Moraes CM, Christ Vianna Santos R, da Costa VL, da Silva GV, da Silva Scherer P, Buaes LE, da Silva Melo DA Donadio MV, Nunes FB, de Oliveira JR: Effect of $\mathrm{N}$-acetylcysteine and fructose-1,6-bisphosphate in the treatment of experimental sepsis. Inflammation 2010. doi: 10.1007/s10753-010-9261-9.

103. Ulloa L, Ochani M, Yang H, Tanovic M, Halperin D, Yang R, Czura CJ, Fink MP, Tracey KJ: Ethyl pyruvate prevents lethality in mice with established lethal sepsis and systemic inflammation. Proc Natl Acad Sci U S A 2002, 99:12351-12356.

104. Xie K, Yu Y, Pei Y, Hou L, Chen S, Xiong L, Wang G: Protective effects of hydrogen gas on murine polymicrobial sepsis via reducing oxidative stress and hmgb1 release. Shock 2010, 34:90-97.

105. Van den Berghe G, Wouters PJ, Bouillon R, Weekers F, Verwaest C, Schetz M, Vlasselaers D, Ferdinande P, Lauwers P: Outcome benefit of intensive insulin therapy in the critically ill: insulin dose versus glycemic control. Crit Care Med 2003, 31:359-366.

106. Ferreira F, Ladrière L, Vincent JL, Malaisse WJ: Prolongation of survival time by infusion of succinic acid dimethyl ester in a caecal ligation and perforation model of sepsis. Horm Metab Res 2000, 32:335-336.

107. Protti A, Carré J, Frost MT, Taylor V, Stidwill R, Rudiger A, Singer M: Succinate recovers mitochondrial oxygen consumption in septic rat skeletal muscle. Crit Care Med 2007, 35:2150-2156.

108. Erl W, Weber C, Wardemann C, Weber PC: Alpha-tocopheryl succinate inhibits monocytic cell adhesion to endothelial cells by suppressing NF-kappa B mobilization. Am J Physiol 1997, 273:H634-H640.

109. King C, Tytgat S, Delude RL, Fink MP: lleal mucosal oxygen consumption is decreased in endotoxaemic rats but is restored toward normal by treatment with aminoguanidine. Crit Care Med 1999, 27:2518-2524.

110. Unno N, Wang H, Menconi MJ, Tytgat SH, Larkin V, Smith M, Morin MJ, Chavez A, Hodin RA, Fink MP: Inhibition of nitric oxide synthase ameliorates endotoxin-induced gut mucosal barrier dysfunction in rats. Gastroenterology 1997, 113:1246-1257.

111. Nin N, Cassina A, Boggia J, Alfonso E, Botti H, Peluffo G, Trostchansky A Batthyány C, Radi R, Rubbo H, Hurtado FJ: Septic diaphragmatic dysfunction is prevented by $\mathrm{Mn}$ (III)porphyrin therapy and inducible nitric oxide 
synthase inhibition. Intens Care Med 2004, 30:2271-2278.

112. Callahan L, Stofan DA, Szweda LI, Nethery DE, Supinski GS: Free radicals alter maximal diaphragmatic mitochondrial oxygen consumption in endotoxin-induced sepsis. Free Radic Biol Med 2001, 30:129-138.

113. Matejović M, Krouzecky A, Martinkova V, Rokyta R Jr, Kralova H, Treska V, Radermacher P, Novak I: Selective inducible nitric oxide synthase inhibition during long-term hyperdynamic porcine bacteremia. Shock 2004, 21:458-465

114. Wang W, Mitra A, Poole B, Falk S, Lucia MS, Tayal S, Schrier R: Endothelial nitric oxide synthase-deficient mice exhibit increased susceptibility to endotoxin-induced acute renal failure. Am J Physiol Renal Physiol 2004 287:1044-1048.

115. Komarov AM, Mak IT, Weglicki WB: Iron potentiates nitric oxide scavenging by dithiocarbamates in tissue of septic shock mice. Biochim Biophys Acta 1997, 1361:229-234

116. Galley HF, Davies MJ, Webster NR: Ascorbyl radical formation in patients with sepsis: effects of ascorbate loading. Free Radic Biol Med 1996, 20:139-143

117. Long CL, Maull KI, Krishnan RS, Laws HL, Geiger JW, Borghesi L, Franks W, Lawson TC, Sauberlich HE: Ascorbic acid dynamics in the seriously ill and injured. J Surg Res 2003, 109:144-148.

118. Goode HF, Cowley HC, Walker BE, Howdle PD, Webster NR: Decreased antioxidant status and increased lipid peroxidation in patients with septic shock and secondary organ dysfunction. Crit Care Med 1995, 23:646-651.

119. Quinlan GJ, Margarson MP, Mumby S, Evans TW, Gutteridge JMC: Administration of albumin to patients with sepsis syndrome: a possible beneficial role in plasma thiol repletion. Clin Sci 1998, 95:459-465.

120. Galley HF, Webster NR: Elevated serum bleomycin-detectable iron concentrations in patients with sepsis syndrome. Intensive Care Med 1996 22:226-229

121. Abilés J, Pérez de la Cruz A, Castaño J, Rodríquez-Elvira M, Aguayo E, MorenoTorres R, Llopis J, Aranda P, Argüelles S, Ayala A, Machado de la Quintana A, Planells EM: Oxidative stress is increased in critically ill patients according to antioxidant vitamins intake, independent of severity: a cohort study. Crit Care 2006, 10:R146.

122. Hotchkiss RS, Morikawa S, Inubushi T, Takahashi K, Ishii H, Ozawa K: Gluconeogenesis and phosphoenergetics in rat liver during endotoxemia. J Surg Res 1998, 74:179-186.
123. Perianayagam MC, Liangos O, Kolyada AY, Wald R, MacKinnon RW, Li L, Rao M, Balakrishnan VS, Bonventre JV, Pereira BJ, Jaber BL: NADPH oxidase p22phox and catalase gene variants are associated with biomarkers of oxidative stress and adverse outcomes in acute renal failure. J Am Soc Nephrol 2007, 18:255-263.

124. Elsakka NE, Webster NR, Galley HF: Polymorphism in the manganese superoxide dismutase gene. Free Radic Res 2007, 41:770-778

125. Huttunen R, Hurme M, Laine J, Eklund C, Vuento R, Aittoniemi J, Huhtala H, Syriänen J: Endothelial nitric oxide synthase G894T (GLU298ASP) polymorphism is associated with hypotension in patients with $E$. coli bacteremia but not in bacteremia caused by a gram-positive organism. Shock 2009, 31:448-453.

126. Mølle I, Ostergaard M, Melsvik D, Nyvold CG: Infectious complications after chemotherapy and stem cell transplantation in multiple myeloma: implications of Fc gamma receptor and myeloperoxidase promoter polymorphisms. Leuk Lymphoma 2008, 49:1116-1122.

127. Marzec JM, Christie JD, Reddy SP, Jedlicka AE, Vuong H, Lanken PN, Aplenc R, Yamamoto T, Yamamoto M, Cho HY, Kleeberger SR: Functional polymorphisms in the transcription factor NRF2 in humans increase the risk of acute lung injury. FASEB J 2007, 21:2237-2246.

128. Sheu CC, Zhai R, Wang Z, Gong MN, Tejera P, Chen F, Su L, Thompson BT, Christiani DC: Heme oxygenase-1 microsatellite polymorphism and haplotypes are associated with the development of acute respiratory distress syndrome. Intensive Care Med 2009, 35:1343-1351.

129. Tang GJ, Huang SL, Yien HW, Chen WS, Chi CW, Wu CW, Lui WY, Chiu JH, Lee TY: Tumor necrosis factor gene polymorphism and septic shock in surgical infection. Crit Care Med 2000, 28:2733-2736.

130. Kolyada AY, Tighiouart H, Perianayagam MC, Liangos O, Madias NE, Jaber BL: A genetic variant of hypoxia-inducible factor-1alpha is associated with adverse outcomes in acute kidney injury. Kidney Int 2009, 75:1322-1329.

doi:10.1186/cc10346

Cite this article as: Andrades ME, et al: Bench-to-bedside review: Sepsis from the redox point of view. Critical Care 2011, 15:230 